\title{
PARTICIPATION OF TENANTS AND THE QUALITY OF MANAGEMENT SERVICES OF COMMUNAL APARTMENTS
}

\section{MICHAŁ DZIADKIEWICZ, ${ }^{1}$ PAWE CICHOWSKI ${ }^{2}$}

Częstochowa University of Technology, POLAND

${ }_{1}^{1}$ e-mail: michaldziadkiewicz@gmail.com

2 e-mail: pawel.piotr.cichowski@gmail.com

RECEIVED
ACCEPTED
JEL
CLASSIFICATION

KEYWORDS

ABSTRACT
22 August 2017

15 December 2017

M14, L32, L85

tenant participation, management services of communal apartments, recovery procedures, public tasks, public enterprises

The article is devoted to the participation of tenants in the management of communal dwellings of local selfgovernment units. The article highlights the impact of this participation on the quality of management of municipal housing. The share of tenants in management was presented on the basis of solutions adopted by the manager of the housing stock of the Municipality of the City of Częstochowa - ZGM TBS Sp. z 0.0. with regard to recovery procedures. The results of the study carried out by this Company in terms of that procedure are also discussed herein, taking into account the causes of the debt.

The article also elaborates on the issue of public tasks resting on municipalities together with an indication of the legal acts on the basis of which these tasks were imposed on municipalities. The forms in which the implementation of public tasks is acceptable, and in particular tasks of satisfying the housing needs of the local community, are also presented here.

\section{Introduction}

Local government units at the municipal level have been appointed in order to perform numerous tasks connected with satisfying collective needs of the local community. Due to their nature, they are referred to as „public tasks". These tasks include, among others, tasks related to the fulfillment of housing needs of that community. 
The implementation of public tasks is of interest to both legal and economic sciences, including the management science (Dębski, 2006).

\section{Satisfying the housing needs as the constitutional task of the municipality}

Imposing the obligation to perform public tasks in terms of meeting the housing needs on units of local selfgovernment already took place in the regulation of the Constitution of the Republic of Poland of 2 April 1997. According to art. 16 (2) of the Basic Law, territorial self-government participates in the exercise of public authority, whereas a substantial part of public tasks that are entitled under the law is performed by the local government on its own behalf and at its own responsibility. From the aforementioned constitutional standard there is a simultaneous commitment to the ordinary legislator to give, in the form of laws, an important part of public tasks to the local government in order to implement them (Skoczylas, Piątek, 2016). As a consequence, a precise assignment of tasks to be performed by municipalities, including those in the discussed scope, was done by means of ordinary laws. As far as the Constitution is concerned, one cannot also omit art. 75 according.

The largest number of public tasks was handed over to municipalities under the Law of 8 March 1990 on the commune self-government. According to art. 6 (1) of this act, all public affairs of local importance, not reserved by law to other entities, fall within the municipality's scope of activity. However, only a sample catalog of these issues was indicated in art. 7 of the Law. Among other things, matters related to the municipal housing construction were distinguished among them.

Another legal act which determines the tasks of municipalities in meeting the housing needs is the Law of 21 June 2001 on the protection of the rights of tenants, municipal housing stock and on amending the Civil Code. According to art. 4 of this law, own tasks of the municipality include the creation of conditions to meet the housing needs of the local community. The municipality, under the rules and in cases provided for in the Law, provides social and substitute housings, but also meets the housing needs of households with low income (Gilowska, 1998; O'Sulivan, Gibb, 2003). The municipality performs these tasks by means of using the municipal housing stock or in some other way (Nowak, Ulfik, 2014). This stock should be understood as premises owned by the municipality, municipal legal persons or commercial companies established with the share of the municipality, except for social housing associations, as well as premises which remain in autonomous possession of these entities. The municipality is entitled to carry out any factual and legal activities which will lead to the acquisition of ownership or spontaneous possession of premises (Doliwa, 2015).

Having owned the housing stock, municipalities are obliged to take appropriate measures which aim at the proper management of that stock. Village mayor, mayor and mayor of the city are competent in this respect. Management, bearing in mind art. 25 (2) in relation to art. 23 (1) of the Act of 21 August 1997 on real estate management, includes among other things activities indicated in the following diagram.

The management of real estate, including residential real estate, covers a very wide range of activities, and particularly independent decisions about the use and purpose of the real estate (Nalepka, 2008; Brzozowska, Starostka-Patyk, 2010).

The concept of real estate management is a term which covers a narrower range of activities. This range may be found in art. 184b, in force since 1 September 2017, of the aforementioned Law on the management of real estate. It covers the steps outlined in Figure 2. 


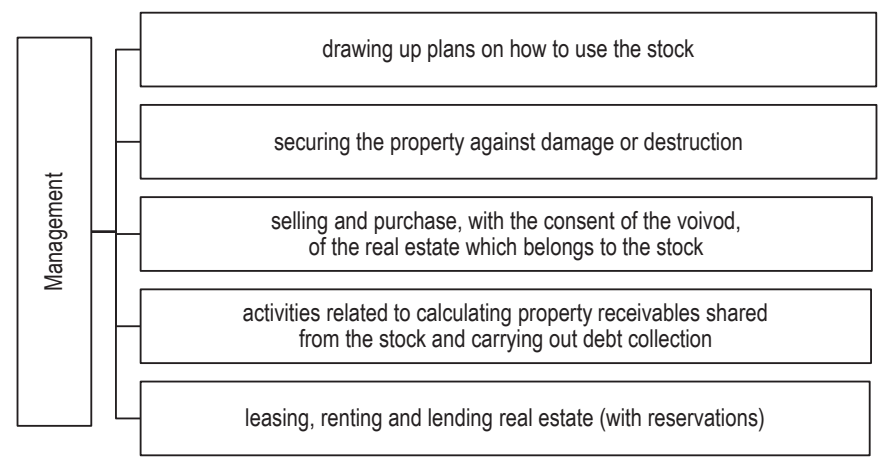

Figure 1. Activities which fall within the scope of management

Source: own elaboration.

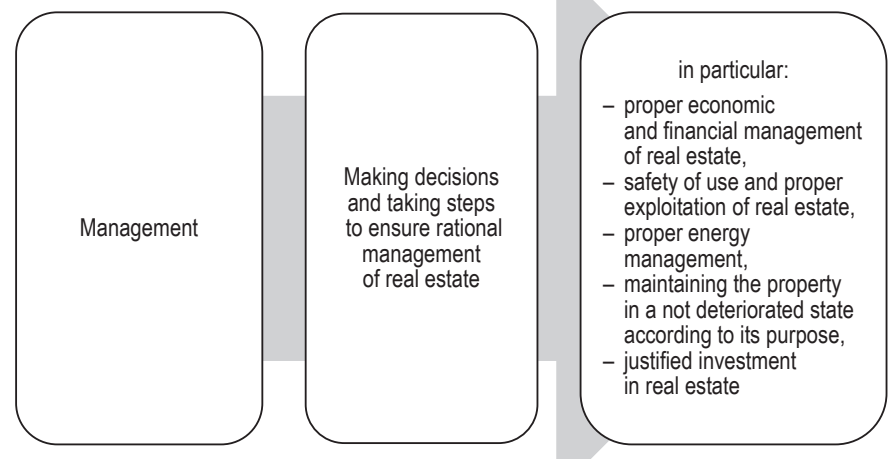

Figure 2. Activities that fall within the scope of management

Source: own elaboration.

However, a detailed scope of activities as well as the powers and duties of the administrator should be defined in each management contract.

Three models can be distinguished in terms of the manner of managing the municipal housing stock.

The direct model predicts that management activities are carried out by the municipal authorities and by the employees of the municipal office. These entities are responsible for decision-making, organization and also the executive function. In the second (indirect) management model, the municipality performs the task in question via its organizational units - budgetary plants, budgetary units, auxiliary properties. Moreover, the task can be implemented through municipal legal persons, and particularly limited liability companies and joint stock companies. In this model, the municipal authorities formulate management strategies as well as the tools to implement them. On the other hand, the aforementioned municipal entities are responsible for organization and implementation of the management process. The last management model includes entrusting the management to other economic entities 
based on the management contract. This model is the so-called management in the custom system (Nalepka, 2008).

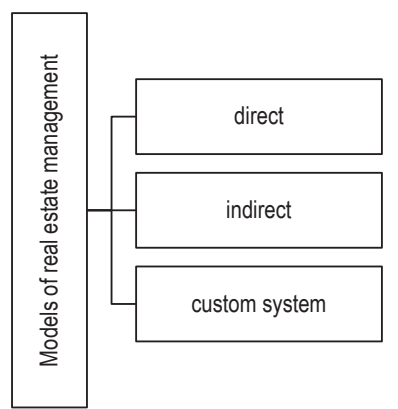

Figure 3. Models of real estate management

Source: own studay based on: Nalepka (2008).

The admissibility of municipalities to choose one of the above-mentioned models of management results directly from the legislation in force. It follows from art. 9 (1) of the Law on municipal self-government that the municipality can create organizational units and conclude agreements with other entities in order to perform its tasks (...). In turn, according to the Law of 20 December 1996 on communal economy, municipal economy may be run by local self-government entities particularly in the form of self-government budgetary plant or commercial law companies (art. 2). By contrast, according to art. 3 of this law, local government units may, by contract, delegate the performance of communal economy tasks to natural persons, legal persons or organizational units without legal personality among other things in accordance with the procedure specified in the Law of 29 January 2004 - Public Procurement Law. What is more, the grounds for entrusting the discussed activities to private entities may be sought in the law on real estate management.

Undoubtedly, each of the presented management models has specific advantages and disadvantages. It seems to be a good solution to choose the indirect model where management takes place through a municipal company. This entity is a separate from the municipality legal person which has among others an ability to self-incur liabilities (Gonet, 2008).

\section{Participation of tenants in shaping the quality of municipal resource management services}

As seen from the above, the management of communal apartments is limited to technical activities such as securing the premises from damage, implementation of legal requirements in the field of safety or administrative and accounting activities. This approach makes the tenants passive participants of the system, because often there is even a lack of the customer-service provider mechanism. The manager's customer is the municipality which commissions a service, whereas the tenant, due to the economic position, is condemned to live in the municipal stock. As a consequence, the "free market" mechanism, resulting in an increase in the quality of management services and the improvement of the quality of the surrounding housing tissue, buildings, green areas, playgrounds and the like, is impaired. 
Taking into account the burden of maintaining the municipal stock connected with some political and economic transformations resulting from the fall of communism (Fehér, Teller, 2016) and the common trend towards the often chaotic privatization of the communal resources, the management of communal premises in Poland was historically limited to a simple model including management and debt collection activities. Such an approach resulted in the widespread trend to destroy the housing stock and the growing queues of residents to social housing, as well as the obligation to pay compensation for the failure to provide social housing in case of eviction from private premises.

Recently, municipalities have been going against the indicated trend. The actions of municipalities mainly concern the debt collection area, which is probably caused by the low efficiency of enforcement proceedings. According to the information of the National Council of Bailiffs, debt collection amounted to only $16 \%$ in 2016 (Information of the National Council of Bailiffs). Furthermore, this tendency can be caused by heavy social consequences of debt collection procedures, which may even lead to eviction into pavement and encourage the phenomenon of falling into the debt spiral, social exclusion or homelessness. Consequently, they can be connected with social pathologies.

The dominant municipal programs are:

- debt restructuring programs, which are usually based on significant one-time cancellations of rent arrears,

- so-called work for rent programs, based on creating possibilities to work off one's rent debt in the form of benefits in kind, which is often associated with the possibility to write off the debt,

- programs run by the so-called Centers for Social Integration.

It can therefore be stated that the way of providing communal services, designed to meet the housing needs of the residents, is evolving towards the indirect model. It involves incorporating at least the weakest economic group of tenants into the process of generating revenue from the municipal stock. This inevitably establishes communication with the management entity (Cairncross, Clapham, Goodlad, 1997; Simmons, Birchall, 2007). In case of programs involving work for rent, the tenants are included in the process of resource management, as they work on cleaning, minor renovations, caring for safety, office work.

However, the observed activities of municipalities are at the beginning of the scale of including tenants into the process of improving the quality of resource management services. There are no examples of extensive indirect models among the municipalities. There are also no examples of the implementation of tenant participation model within the process of communal management, although literature points out its advantages. These include for example:

- mobilizing tenants to care for the resources, which they start to perceive as the common good (Chapman, Kirk, 2001),

- common understanding of resource management rules, thereby an increase in the acceptance of the tenants' obligations e.g. related to rent payment,

- improving the functionality and attractiveness of the housing tissue as a common space to live (Bengtsson, 1995),

- creating social bonds between tenants, and at the same time counteracting unfavorable phenomena related to social exclusion (Jadach-Sepioło, Jarczewski, 2015; Carroll, 1999). 


\section{Including tenants in the process of municipal resource management on the example of the Municipality of Częstochowa}

The management of the municipal housing stock in the Municipality of Częstochowa is carried out by a limited liability company that is owned by the Municipality - the Department of Housing Management Social Housing Association in Częstochowa LLC (hereafter: ZGM, Company). As part of its activity, the Company also performs a function related to the provision of municipal management services. In terms of debt collection activities, the Company has faced a problem of negative attitudes of tenants regarding the fulfillment of rent obligations or problems with the execution of evictions (lack of social housing). Finally, ZGM came into contact with the debtors who are affected by the so-called debt spiral - people whose execution does not even cover the interest and the costs of the process.

In response to these issues, the Company has implemented a number of programs aimed at restructuring the tenants' debts, such as:

- „work for rent” program,

- debt recovery (i.e. working it off) program as part of the Center for Social Integration,

- program of voluntary housing exchange,

- possibility of spreading the debt into installments and redemption of part of the debt in the scope of side benefits.

Moreover, the Company undertakes a series of initiatives in order to reinforce positive attitudes of the residents towards the payment of rent fees. Among them are the annual editions of the "Reliable Tenant” competition or Neighbor Days. ZGM also undertakes actions to simplify the „procedure” of rent payment.

Due to the observed effects, it was decided to carry out a study of attitudes and behaviors of the debtors against whom debt collection procedures were initiated, concerning the payment of fees for the premises and the security within the housing stock. The study was conducted in November 2016 in the form of a questionnaire survey. 299 subjects were surveyed, which fulfills the requirements of the sample representativeness.

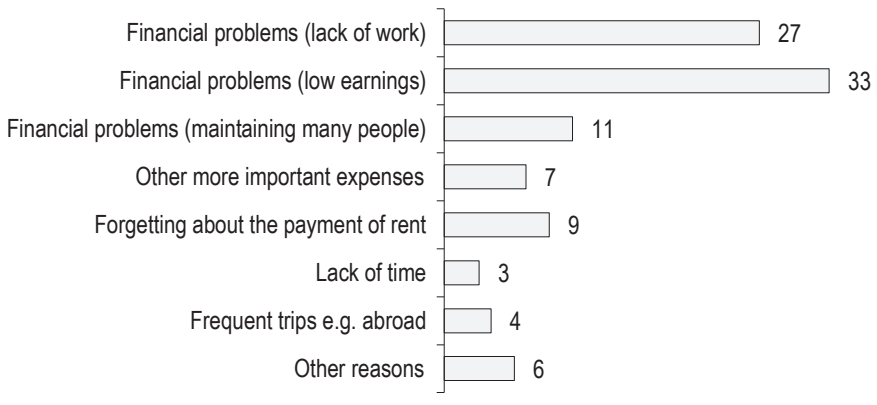

Figure 4. Main reasons for not paying rent

Source: own study based on studies commissioned by ZGM TBS Sp. z o.o. in Częstochowa. 


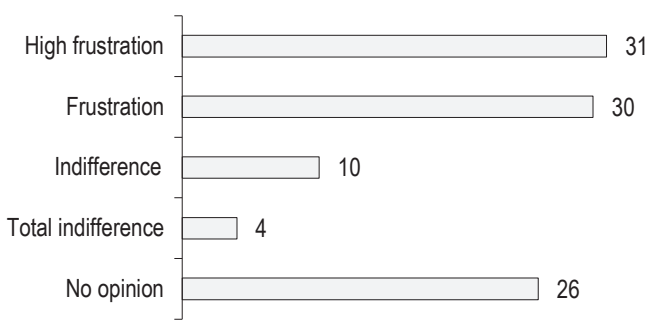

Figure 5. Tenants' feeling on initiating the debt collection procedure

Source: own study based on studies commissioned by ZGM TBS Sp. z o.o. in Częstochowa.

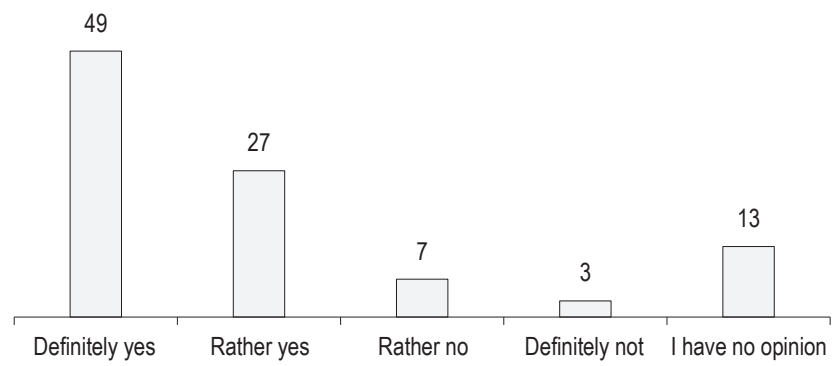

Figure $\boldsymbol{b}$. Concerns about the consequences of initiating debt collection procedures

Source: own study based on studies commissioned by ZGM TBS Sp. z o.o. in Częstochowa.

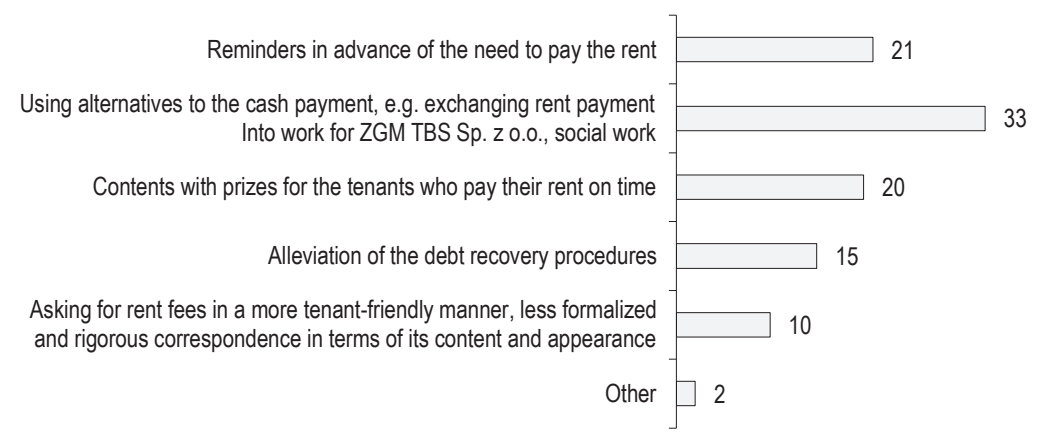

Figure 7. Incentives for the tenants to pay the rent

Source: own study based on studies commissioned by ZGM TBS Sp. z 0.0. in Częstochowa.

The study confirms that rent arrears are a result of financial problems and reaffirms the intuitive conviction that fees for apartment are no longer paid in case of the objective inability to pay them - financial problems resulting from unemployment, low income and a great number of children belonged to the group of $71 \%$ of debtors. The survey, 
however, has shown that there is room to improve information policy as $16 \%$ of the subjects were overdue for rent due to forgetfulness or, for instance, going abroad. The study has confirmed that the implementation of debt collection procedures causes discomfort in the residents $-61 \%$ of the debtors referred to it. However, it is worth noting that a group of nearly $40 \%$ respondents do not react to the threat of court debt collection. Bearing in mind the low efficiency of bailiff enforcement, other forms of debt collection should be dedicated to convincing these debtors to pay rent fees at least at the level of one's will.

In the course of the study, it was found that the debtors were aware of the debt relief programs implemented by the Company and considered them useful in increasing the effectiveness of debt collection. Nearly $33 \%$ of the subjects found it important to implement programs of working off the debts and to negotiate repayments (in the form of spreading them into installments and partial amortization). Significantly, almost $21 \%$ of the subjects pointed out the importance of information policy - adequate information about debts.

\section{Conclusions}

Analysis of the case of the Municipality of Czesstochowa allows to put forward the thesis about the appropriateness of including tenants in the process of managing premises. The debt collection area itself allows to state that some of the problems with paying debts are solved by the properly suited information policy as well as the possibility to participate in debt relief programs. It should also be noted that the provider of the management service supports the management of the tenants' budgets by means of avoiding the most serious financial problems connected with the so-called debt spiral.

Conclusions regarding the inclusion of tenants in debt collection procedures of the administrator can certainly be extended to other management issues. Therefore, it can be concluded that the participation of tenants in the management of communal apartments is a tool of great potential, allowing to increase the quality of the management services, to improve the quality of life in common space and to counteract negative phenomena resulting from social exclusion.

\section{References}

Bengtsson, B. (1995). Housing - Market Commodity of the Welfare State, materials of the Institute of Housing Research. Gävle.

Brzozowska, A., Starostka-Patyk, M. (2010). Determinants of Outsourcing Process. Freiberger Forschungshefte. D 238 Wirtschaftswissenschaften, 3-17.

Cairncross, L., Clapham, D., Goodlad, R. (1997). Housing Management, Consumers and Citizens, Routledge. New York.

Carroll, A.B. (1999). Corporate Social Responsibility: Evolution of a Definitional Construct. Business and Society, 3 (38), $268-295$.

Chapman, M., Kirk, K. (2001). Lessons for Community Capacity Building: A Summary of Research Evidence, Scottish Homes. Edinburgh.

Fehér, B., Teller, N. (2016). An Emerging Research Strand: Housing Exclusion in Central and South East Europe. European Journal of Homelessness, 3 (10), 67-85.

Gilowska, Z. (1998). System ekonomiczny samorządu terytorialnego w Polsce. Warszawa.

Gonet, W. (2008). Uwagi o formach prowadzenia gospodarki komunalnej. Samorząd Terytorialny, 7-8, 72.

Information of the National Council of Bailiffs (2017). Retrived from: www.rp.pl (18.07.2017).

Jadach-Sepioło, A., Jarczewski, W. (2015). Housing Policy as a Part of Urban Regeneration Policy - The Case of Poland. Journal of Business and Economics, 2 (6), 381-392.

Nalepka, A. (2008). System zarządzania zasobem nieruchomości gminy. Zarządzanie nieruchomościami, 64, 5-9. 
Nowak, S., Ulfik, A. (2014). An evaluation of regional development in the context of economic and environmental benefit. Polish Journal of Management Studies, 1 (10), 74-83.

O'Sulivan, T., Gibb, K. (2003). Housing Economics and Public Policy. Blackwell Science.

Simmons, R., Birchall, J. (2007). Tenant Participation and Social Housing in the UK: Applying a Theoretical Model. Housing Studies, 4 (22), 573-595.

Skoczylas, A., Piątek, W. (2016). In: M. Safjan, L. Bosek (eds.), Konstytucja RP. Tom I. Komentarz art. 1-86. Legalis.

Cite this anticle aS: Dziadkiewicz, M., Cichowski, P. (2018). Participation of tenants and the quality of management services of communal apartments. European Journal of Service Management, 2 (26), 61-69. DOI: 10.18276/ejsm.2018.26-08. 